\title{
A Study on the Rate of Return of Infrastructure Projects for Joint Venture
}

\author{
Sang Hyuk Lee, Ph.D. ${ }^{1}$ and Myungsik Do, Ph.D. ${ }^{2^{*}}$ \\ ${ }^{1}$ Senior Researcher, Korea Institute of Construction Technology \\ Sanghyuklee8612@gmail.com \\ ${ }^{2}$ Professor, Hanbat National University \\ msdo@hanbat.ac.kr
}

\begin{abstract}
In the last decade, the Korean government has faced with reducing budgets for necessary infrastructure constructions. As a reason, private investment was introduced for overcoming this circumstance. Private investment called as joint venture is effective and efficient method to implement infrastructure projects in Korea due to budget constraints of the government. In order to vitalize private investment, certain level of profits from investments should be guaranteed. Nevertheless proper rate of return has not been defined yet because of fluctuating economic indicators and uncertain expectation of economic condition in future. Therefore, this study proposed the proper rate of return for private investment to infrastructure projects in Korea using three approaches such as estimate from existing private investment $s$, various economic indicators and rate of returns on financial investments.
\end{abstract}

Keywords: Private investment, Rate of return, Infrastructure projects

\section{Introduction}

Investing to infrastructure facilities is essential in order to enhance national competitiveness and improve the living standard. These investments for infrastructures need enormous finances which are mostly raised by the government. However the total budget for constructing infrastructure facilities has been continuously declined because of the Asian Financial Crisis in 1997. Thus the government has actively encouraged private investment referred to as joint ventures to infrastructure projects, and then the joint venture becomes the key role on constructing infrastructure facilities to overcome budget constraint for the government. As a result, a scale of investment from joint ventures grows $4.4 \%$ in 1998 to $11.7 \%$ in 2012 out of total investment budget. Even though private investment to infrastructures has increased, some problems have been arisen such as financial burden of the government and erroneous demanding forecasts. So these problems could be obstacles to succeed private investment to infrastructure projects.

Especially, the certain amount of private investor profits could not be guaranteed from the projects. Therefore private investors have conducted project feasibility analysis before participating constructing and operating infrastructure projects. So far, even though operational revenue from the infrastructure projects could not reach to the specific levels of profits which private investors plan, the government supplements the lack of revenue according to Minimum Revenue Guarantee (MRG) or Standard Cost Support (SCS) policies. However these policies will be abolished at near future because of the financial burden of the government and moral hazard of the private investors.

${ }^{*}$ Corresponding Author 
Hence, the private investors have to estimate more accurate rate of return in project feasibility analysis. Nevertheless, the proper rate of return from infrastructure projects could not be defined in private investors' point of view. So this study proposes appropriate rate of return for private investment of infrastructure projects and also provides basic information and current status of the private investment in Korea as well.

\section{Current Status and Characteristics of the Joint Venture in Korea}

\subsection{Status of the Joint Venture}

The infrastructure can be defined as facilities and policies for a base of economic activity and welfare activity such as energy facilities, highways, rails, airports, seaports and also educational and medical facilities as well. In these infrastructures, the biggest portion of capacity in infrastructures in transportation related infrastructures in Korea. Also the capacity of infrastructures has been expanded for 30 years because of urban sprawl and some political reasons. However the government has faced budget constraints after the Asian Financial Crisis. Therefore the government has encouraged the private sector which is formed as joint venture to participate constructing and operating infrastructure projects.

Private investment has been continuously increasing since the introduction of the Act on Private Partnership in Infrastructure (PPI) and has become a key role in providing infrastructure in a timely manner, complementing for lack of public investment. In 1999, PPI Act was amended for stimulating investments in infrastructures of private investors, therefore, proportion of private investment in the total infrastructure projects grew from $1 \sim 5 \%$ in 90 s to about $13 \%$ in 2009. However private investments shrank after 2009 because benefits of PPI Act were reduced. Nevertheless, private investment is expected to continue to increase in the future.

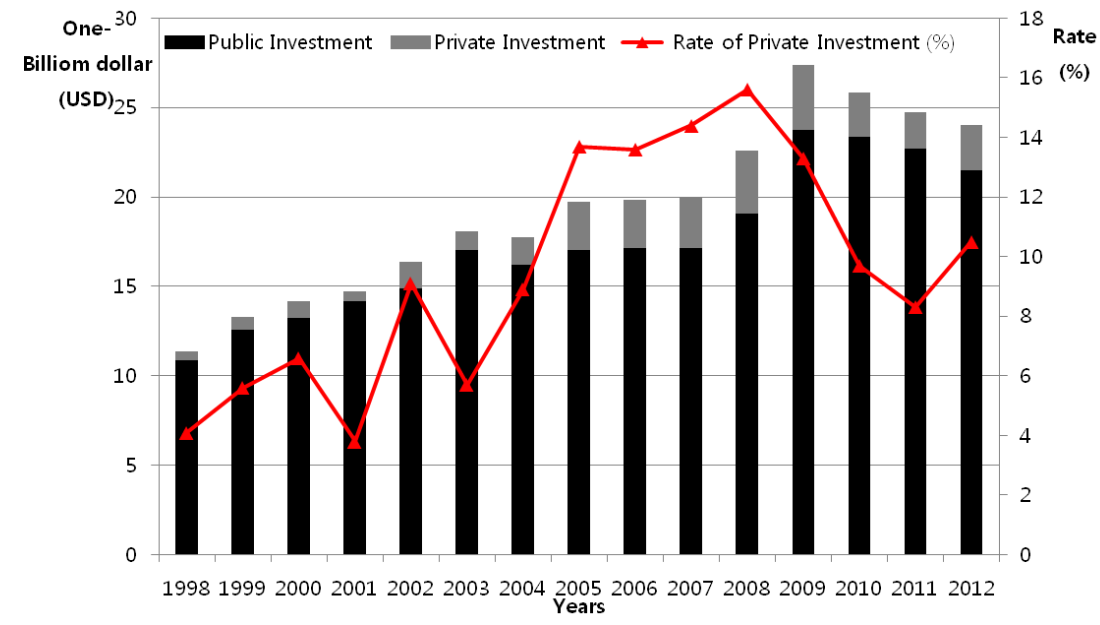

Figure 1. Trends of Private Investment

Usually the contracts of private investment utilize specific methods such as BuildTransfer-Operate (BTO), Build-Operate-Transfer (BOT), Build-Own-Transfer (BOO) and Build-Transfer-Lease (BTL) in Korea. Also private investment can be classified into three types depending on financial support sources such as the central government management projects, the local government management projects, and the local government management projects supported by the central government. Up to now, total 654 private investment projects are in operations and under constructions. Among them, 165 projects with 54.0 billion USD private investments are managed by the central government. Also 
308 projects including roads, tunnels, seaports, parking garages, environmental facilities with 13.3 billion USD private investments are managed by the local governments. Especially the environment-related projects show a significant increase. This means that private investment diversifies into other areas such as environmental business and tourism etc., instead of transportation projects oriented by the central government.

Table 1. Proportion of Private Investment from Government Investment

\begin{tabular}{|c|c|c|c|c|c|c|}
\hline & Methods & $\begin{array}{c}\text { \# of } \\
\text { Projects }\end{array}$ & Proportion & $\begin{array}{l}\text { Amount of } \\
\text { Investment } \\
\text { (Billion USD) }\end{array}$ & Proportion & $\begin{array}{l}\text { Amount of } \\
\text { Investment } \\
\text { per Project } \\
\text { (100 Million } \\
\text { USD) }\end{array}$ \\
\hline \multirow{5}{*}{$\begin{array}{l}\text { Managed by } \\
\text { Central } \\
\text { Government }\end{array}$} & BTO & 60 & $36.4 \%$ & 42.0 & $77.9 \%$ & 7.0 \\
\hline & BOT & 1 & $0.6 \%$ & 0.3 & $0.5 \%$ & 2.9 \\
\hline & $\mathrm{BOO}$ & 4 & $2.4 \%$ & 0.8 & $1.5 \%$ & 2.0 \\
\hline & BTL & 100 & $60.6 \%$ & 10.9 & $20.1 \%$ & 1.1 \\
\hline & Sum & 165 & $100.0 \%$ & 54.0 & $100.0 \%$ & 3.3 \\
\hline \multirow{3}{*}{$\begin{array}{l}\text { Managed by } \\
\text { Local } \\
\text { Government with } \\
\text { Central } \\
\text { Government } \\
\text { Support }\end{array}$} & BTO & 31 & $19.3 \%$ & 14.3 & $66.5 \%$ & 4.6 \\
\hline & BTL & 130 & $80.7 \%$ & 7.2 & $33.5 \%$ & 0.6 \\
\hline & Sum & 161 & $100.0 \%$ & 21.5 & $100.0 \%$ & 1.3 \\
\hline \multirow{5}{*}{$\begin{array}{l}\text { Managed by } \\
\text { Local } \\
\text { Government }\end{array}$} & BTO & 109 & $35.4 \%$ & 5.4 & $40.7 \%$ & 0.5 \\
\hline & BOT & 2 & $0.6 \%$ & 0.3 & $2.2 \%$ & 1.4 \\
\hline & $\mathrm{BOO}$ & 4 & $1.3 \%$ & 0.5 & $3.5 \%$ & 1.2 \\
\hline & BTL & 193 & $62.7 \%$ & 7.1 & $53.6 \%$ & 0.4 \\
\hline & Sum & 308 & $100.0 \%$ & 13.3 & $100.0 \%$ & 0.4 \\
\hline
\end{tabular}

Source: KDI (2013)

\subsection{Prospects of the Joint Venture in Future}

The investment for constructing infrastructures will be continuously needed for providing necessary infrastructures in right time to enhance national competitiveness and activating construction business to recovery economic conditions. However the government has faced the difficulties to secure budgets for infrastructure investments. Therefore the needs for increased private investment could likely be more to supplement budget constraint. According to 'Mid-and Long Term Budget Demand Analysis in National Main projects, National Assembly Budget Office 2009', budget needed for infrastructures from 2009 to 2020 would be about 84 billion USD and would be mainly transportation related infrastructures.

Table 2. The Prospect of Private Investment in Future (2009 2020)

\begin{tabular}{|c|c|c|}
\hline Types of Infrastructure & Investment Demands (billion USD) & Ratio (\%) \\
\hline Roads & 39.32 & 46.67 \\
\hline Seaports & 1.39 & 1.64 \\
\hline Rails & 38.44 & 45.63 \\
\hline
\end{tabular}




\begin{tabular}{|c|c|c|}
\hline City Rails & 2.79 & 3.31 \\
\hline Airports & 0.01 & 0.01 \\
\hline Logistics and Others & 2.31 & 2.74 \\
\hline Total & 84.26 & 100.00 \\
\hline
\end{tabular}

Source: National Assembly Budget Office (2009)

\subsection{Characteristics of the Joint Venture}

In spite of increasing private investment demands, private investors have also difficulties to raise funds for investing infrastructure projects. First reason is that private investment projects need huge scales of early stage investment, however, the investment collection periods are around 20 30 years after completing construction. Also raising financial funds of private investors in infrastructure projects has a couple of problems; first, private investors participating in infrastructure projects are mainly consisted of construction companies and outside capitals of private investors are mainly consisted of financial capitals and bond issues. It means that private investor should accept the higher risk of financial investment to the infrastructure projects because the certain levels of rate of profits should be guaranteed for financial expenses in long-term periods. Fortunately, the risk of financial investment can be shared with the central or local government through MRG or SCS policies. Nevertheless, private investors should be cautious to make decision for investment of infrastructure projects. Thus investment feasibility analysis should be conducted before investing to infrastructure projects according to criteria of proper rate of return for private investors.

\section{Criteria of Return Rate on Investment}

Investment projects of private investments should be considered with proper levels of return rates. However return on investment of infrastructure projects usually appears in long term periods. So discount rate is appropriate index to evaluate feasibility assessment of projects. Discount rate can be decided based on opportunity cost of capital. Opportunity cost of capital can be defined as return rate of capital investments in other opportunities.

Discount rate can be classified into two types such as social discount rate and private discount rate. Social discount rate usually uses for evaluating public projects. Social discount rate is an index converting future value of the benefits and losses into present value of public projects. However private discount rate can be defined as expected return rate when company capital invests other businesses. Private investors are only interested of private discount rate because private investors seek future cash flows from the investments or profits of the opportunity cost of invested capital return in order to achieve corporate goals.

In private investment of the government-led projects, the government suggests a guideline of rate of return by preliminary feasibility analysis. On the other hand, in private investment of the private investor-led projects, private investors suggest proper levels of rate of return through their own feasibility analysis. After then, the rate of return for projects can be determined by an agreement between the government and private investors. The basic level of rate of return for the private investment projects can be composed as follow.

$$
\sum_{i=0}^{n} \frac{C C i}{(1+r)^{i}}=\sum_{i=n+1}^{N} \frac{P R i-O C i}{(1+r)^{i}}+\sum_{i=0}^{N} \frac{A N R i}{(1+r)^{i}}
$$

Where, 
$N=$ free operating period or at the end of operating period

$C C i=$ annual costs for completion of facilities (excluding the government financial aid)

$P R i=$ annual operating revenue

$O C i=$ annual operating costs

$A N R i=$ annual net gain from projects (revenue-costs)

$r=$ rate of return of projects (IRR)

Feasibility analysis of constructing and operating infrastructures is a very importation procedure to determine participation of projects and to decide methods of projects. Feasibility analysis can be classified into two types such as economic feasibility analysis and financial feasibility analysis. Economic feasibility analysis is an assessment tool for calculating costs and benefits of public projects and for deciding project feasibility according to economical rate of return. In contrast, financial feasibility analysis is a method of project feasibility for normally private investors through calculating financial rate of return using estimated financial costs and benefits. Therefore financial feasibility analysis attaches great importance to investment budgets and cash flows of projects.

Comparing with economical feasibility analysis, financial feasibility analysis uses the market price and market interest rate (private interest rate) as analysis variables instead of the shadow price and social discount rate respectively. Also financial feasibility analysis has to consider taxes, discount costs, and reserve fund for price etc. Thus this study considers proper rate of return for private investment in infrastructure based on financial feasibility analysis.

\section{Estimate of Proper Return Rate on Investment}

This study is to estimate proper rate of return on private investment in infrastructure projects using three approaches; 1) estimate from case study of existing infrastructure projects related with private investment, 2) estimate from various interest rates in the markets, and 3 ) estimate from expected rate of return in financial investments.

\subsection{Estimate from Existing Private Investment Projects}

In this section, private investment projects in operation are examined for rate of return on existing private investment projects in Korea.

Table 3. Information of Targeted Private Investment Projects

\begin{tabular}{|c|c|c|c|c|c|c|}
\hline Type & Projects & $\begin{array}{c}\text { Total project } \\
\text { cost (million \$) }\end{array}$ & $\begin{array}{c}\text { Financial aid } \\
(\text { million } \$)\end{array}$ & $\begin{array}{c}\% \text { of private } \\
\text { investment }\end{array}$ & $\begin{array}{c}\% \text { of equity } \\
\text { capital }\end{array}$ & $\begin{array}{c}\text { Rate of } \\
\text { Return }(\%)\end{array}$ \\
\hline Port & Pusan Newport & 1533.3 & 464.5 & 74.5 & 26.8 & 9.50 \\
\hline Port & New Mokpo Outer Port & 78.4 & 34.4 & 57.5 & 40.9 & 9.52 \\
\hline Road & Cheolma Mountain Tunnel & 72.4 & 32.6 & 57.4 & 30.0 & 8.57 \\
\hline Road & Daegu-Pusan Expressway & 1825.5 & 543.1 & 72.3 & 32.6 & 9.38 \\
\hline Road & Cheonan-Nonsan Expressway & 1338.5 & 389.6 & 72.2 & 36.2 & 9.24 \\
\hline Road & Manwol Mountain Tunnel & 100.5 & 31.2 & 75.0 & 27.0 & 8.86 \\
\hline Road & Seoul Ring Road & 1360.7 & 403.1 & 72.8 & 29.9 & 9.52 \\
\hline Road & Incheon Int. Airport Exp. & 1248.8 & 0.0 & 100.0 & 29.4 & 9.70 \\
\hline Etc & $\begin{array}{c}\text { Incheon International Airport } \\
\text { Freight Terminal IC }\end{array}$ & 37.8 & 0.0 & 100.0 & 30.0 & 5.90 \\
\hline Road & Gwangju Ring Road 2-1 & 137.7 & 0.0 & 100.0 & 30.0 & 9.34 \\
\hline Environ & Yangpyeong waste incinerating & 3.7 & 2.6 & 30.0 & 100.0 & 8.34 \\
\hline Environ & $\begin{array}{l}\text { Pyeongtaek terminal disposal } \\
\text { plant of sewage }\end{array}$ & 71.3 & 29.2 & 60.2 & 30.0 & 6.40 \\
\hline Port & Gunsan BiUng Port & 91.7 & 44.8 & 31.4 & 65.7 & 8.38 \\
\hline Port & Incheon Northport & 176.4 & 53.1 & 72.1 & 30.0 & 8.86 \\
\hline Environ & Heocheon-Beolgyo Terminal & 20.7 & 14.1 & 32.3 & 44.7 & 5.15 \\
\hline
\end{tabular}




\begin{tabular}{|c|c|c|c|c|c|c|}
\hline & Disposal Plant of Sewage & & & & & \\
\hline Road & Gochon-Wolgot Road & 122.7 & 0.0 & 100.0 & 25.0 & 8.66 \\
\hline Environ & Hwaseong Sewage Treatment & 86.5 & 66.2 & 25.0 & 25.0 & 6.30 \\
\hline Environ & Sudokwon Landfill & 71.9 & 0.0 & 100.0 & 25.0 & 8.44 \\
\hline Road & Machang Bridge & 242.9 & 67.5 & 75.4 & 20.0 & 8.86 \\
\hline Road & Pusan-Geoje Connecting Road & 1346.2 & 416.2 & 72.2 & 26.2 & 9.49 \\
\hline Road & Umyeonsan Mountain Tunnel & 145.9 & 0.0 & 100.0 & 31.6 & 8.03 \\
\hline Rail & Pusan-Gimhae LRT & 720.3 & 272.0 & 65.0 & 27.1 & 9.10 \\
\hline Rail & Incheon int. Airport Exp. Train & 2919.1 & 710.0 & 75.0 & 30.0 & 10.43 \\
\hline Road & Kangnam Beltway & 675.9 & 181.4 & 80.1 & 30.0 & 8.48 \\
\hline Road & Siheung-Namdong Road & 447.5 & 0.0 & 100.0 & 25.0 & 8.28 \\
\hline Road & Seoul-Chuncheon Expressway & 1330.1 & 398.6 & 72.1 & 25.0 & 8.00 \\
\hline Road & Yongin-Seoul Road & 720.3 & 269.8 & 64.1 & 25.0 & 7.01 \\
\hline Road & West Suwon Pyeongtaek Exp. & 797.3 & 231.2 & 72.2 & 30.0 & 7.40 \\
\hline Environ & Yongin Sewage Treatment & 371.7 & 324.4 & 13.1 & 100.0 & 5.65 \\
\hline Etc & $\begin{array}{c}\text { Central Integrated Freight } \\
\text { Terminal }\end{array}$ & 102.9 & 0.0 & 100.0 & 24.3 & 5.82 \\
\hline Environ & Incheon Int. Airport Fueling & 96.6 & 0.0 & 100.0 & 38.0 & 3.92 \\
\hline Road & Daejeon Riverside Expressway & 155.8 & 0.0 & 100.0 & 20.9 & 8.30 \\
\hline Environ & $\begin{array}{c}\text { Songdo-Mansu Terminal Disposal } \\
\text { Plant of Sewage }\end{array}$ & 79.6 & 0.0 & 100.0 & 30.0 & 6.93 \\
\hline Environ & Jeonju Sewage Treatment & 39.9 & 31.4 & 21.5 & 56.6 & 6.31 \\
\hline Road & Yongma Tunnel & 100.3 & 0.0 & 100.0 & 30.0 & 7.47 \\
\hline Road & Gwangju Ring Road 2-4 & 158.0 & 30.6 & 81.5 & 30.0 & 8.04 \\
\hline Environ & Jeonbuk Environmental & 188.5 & 132.0 & 31.0 & 30.0 & 6.55 \\
\hline Environ & Geomdan Sewage Treatment & 63.6 & 47.7 & 24.1 & 30.2 & 5.98 \\
\hline Environ & Byeokje-Ilsan Treatment & 36.8 & 19.5 & 27.2 & 45.0 & 6.01 \\
\hline Environ & Musan Drainage System & 33.4 & 25.5 & 24.8 & 30.0 & 6.42 \\
\hline Environ & $\begin{array}{l}\text { Jinbu-Daehwa Terminal Disposal } \\
\text { Plant of Sewage }\end{array}$ & 16.4 & 13.6 & 17.2 & 40.0 & 6.03 \\
\hline Environ & Nonsan Daily Waste Incinerating & 8.5 & 2.4 & 71.8 & 32.1 & 5.61 \\
\hline Etc & $\begin{array}{c}\text { Gunpo Integrated Freight } \\
\text { Terminal } \\
\end{array}$ & 301.8 & 33.0 & 90.3 & 21.0 & 7.10 \\
\hline Rail & Sinbundang Railroad & 1070.2 & 513.7 & 53.2 & 25.0 & 8.00 \\
\hline Environ & Gimcheon Environ. Treatment & 29.2 & 16.8 & 43.7 & 30.1 & 5.50 \\
\hline Etc & $\begin{array}{c}\text { Yeongnam Integrated Freight } \\
\text { Terminal }\end{array}$ & 126.5 & 0.0 & 100.0 & 25.0 & 5.82 \\
\hline
\end{tabular}

Source: Private Infrastructure Investment Center of Korea (2005)

The targeted projects in this study are 46 projects which are already executed agreements or executing agreements. Table 3 describes information of targeted projects including total project costs, capacity of financial aid from the government, percentage of private investment in each project, percentage of equity capital in each project, and real rate of return. According to analysis of the targeted projects, the average percentage of private investment accounts for around $70 \%$ of total project costs and the average of real rate of return is around $7.80 \%$. In comparing with project types, the highest rate of return in project types is railroad as $9.18 \%$ and rate of returns in other project types such as ports, roads, environments and others are $9.07 \%, 8.56 \%, 6.22 \%$ and $6.16 \%$ respectively.

Actually rate of return of projects can be determined by size and scale of project risks, the percentage of private investment, the percentage of equity capital and the government subsidies (MRG and SCS). Also this study has a limitation to generalize analysis results because only 46 projects out of 634 projects in 2012 are examined. Nevertheless, in most cases, it tends to increase rate of return, when targeted projects have more financial risks, percentage of private investment, percentage of equity capital and less the government subsidies. Figure 2, 3 depicts the relationships between the percentage of private investment and rate of return and between the percentage of equity capital and rate of return respectively. 


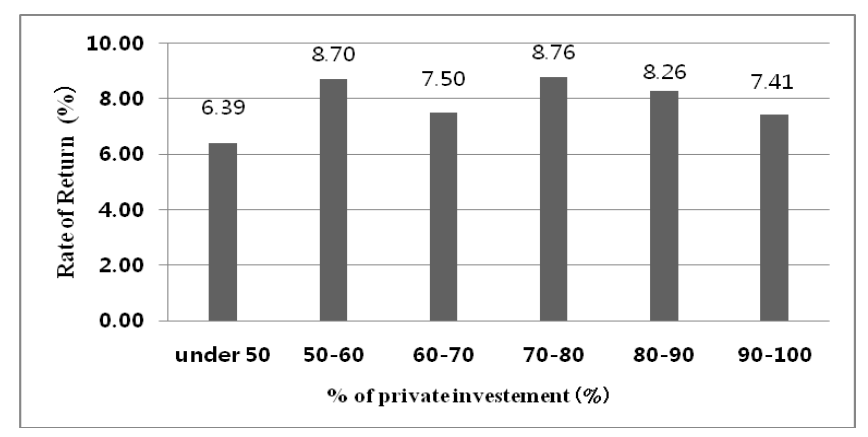

Figure 2. Relationship between Percentage of Private Investment and Rate of Return

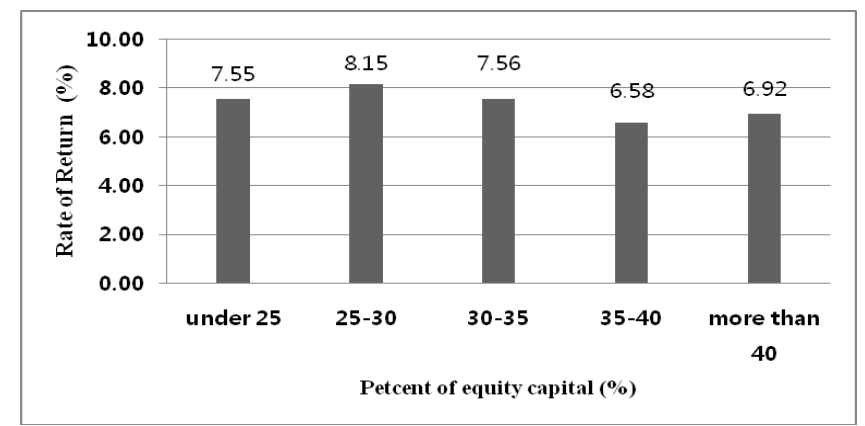

Figure 3. Relationship between Percentage of Equity Capital and Rate of Return

\subsection{Estimate from Various Economic Indicators}

After global economic recession, interest rates have been decreased continuously and have been stable since 1997 in Korea. Thus private investors have looked for new investment markets to get more benefits than profits from financial investment. As mentioned above, higher rate of return can be expected in higher risk circumstances of investments for infrastructure projects. Therefore it is complicated to make decisions for certain levels of risk, which private investor can be borne, and proper rate of return, which private investors can be expected. When private investors conduct estimates of proper rate of return for investment to infrastructure projects, usually two types of rate of returns should be considered such as risk-free rate of return and risk premium rate of return. However this study considers risk-free rate of return to estimate proper rate of return for investments to infrastructure projects because most of infrastructure projects involved in private investments in Korea can be guaranteed for certain level of revenue by the government using MRG and SCS policies.

Generally speaking, risk-free rate of return is considered to be same as the commercial interest rates, and as shown in Table 4, commercial interest rates are variable. Since 1999, after Asian Financial Crisis, commercial interest rates show a downtrend and stable trend in Korea. Based on Table 4, the average of risk-free rate of return would be 3.8 6.4\%. Lower $4.0 \%$ of interest rates would be affected by low-interest policy of the government, and low-interest policy could be temporarily held. However many economists anticipate that expected risk-free rate of return could be around $4.5 \sim 5.5 \%$ for a while. 
Table 4. Annual Commercial Interest Rates in Korea

\begin{tabular}{|c|c|c|c|c|c|c|}
\hline \multirow{2}{*}{ Year } & \multicolumn{2}{|c|}{ Bank Interest Rate } & \multicolumn{4}{c|}{ Market Interest Rate } \\
\cline { 2 - 6 } & $\begin{array}{c}\text { Deposit } \\
\text { Interest }\end{array}$ & $\begin{array}{c}\text { Loan } \\
\text { Interest }\end{array}$ & Call Rate & $\begin{array}{c}\text { Rate of } \\
\text { Return of } \\
\text { CD }\end{array}$ & $\begin{array}{c}\text { Rate of } \\
\text { Return of } \\
\text { Corporate } \\
\text { Bond }\end{array}$ & $\begin{array}{c}\text { Rate of } \\
\text { Return of } \\
\text { Government } \\
\text { Bond }\end{array}$ \\
\hline 1998 & 13.30 & 15.18 & 15.07 & 15.22 & 15.10 & 12.94 \\
\hline 1999 & 6.90 & 9.40 & 4.93 & 6.81 & 8.86 & 7.69 \\
\hline 2000 & 7.01 & 8.55 & 5.05 & 7.08 & 9.35 & 8.30 \\
\hline 2001 & 5.43 & 7.70 & 4.65 & 5.32 & 7.05 & 5.68 \\
\hline 2002 & 4.69 & 6.58 & 4.30 & 4.90 & 5.88 & 5.28 \\
\hline 2003 & 4.20 & 6.27 & 4.01 & 4.35 & 5.45 & 4.58 \\
\hline 2004 & 3.75 & 5.90 & 3.59 & 3.79 & 4.73 & 4.11 \\
\hline 2005 & 3.62 & 5.59 & 3.41 & 3.65 & 4.68 & 4.27 \\
\hline 2006 & 4.41 & 5.99 & 4.30 & 4.48 & 5.17 & 4.83 \\
\hline 2007 & 5.07 & 6.55 & 4.86 & 5.16 & 5.70 & 5.23 \\
\hline 2008 & 5.71 & 7.17 & 5.05 & 5.49 & 7.02 & 5.27 \\
\hline 2009 & 3.26 & 5.65 & 2.42 & 2.63 & 5.81 & 4.04 \\
\hline 2010 & 3.19 & 5.51 & 2.43 & 2.67 & 4.66 & 3.72 \\
\hline 2011 & 3.69 & 5.76 & 3.23 & 3.44 & 4.41 & 3.62 \\
\hline 2012 & 3.43 & 5.40 & 3.18 & 3.30 & 3.77 & 3.13 \\
\hline 2013 & 2.73 & 4.64 & 2.01 & 2.72 & 3.19 & 2.79 \\
\hline S0urceryyyyy \\
\hline
\end{tabular}

Source: The Bank of Korea

\subsection{Estimate from Rate of Return on Financial Investments}

Private investors for infrastructures projects are normally made up of construction companies, public corporations of pension and fund, banks and insurance companies. Of these, construction companies usually pursue construction profits, whereas other private investors make profits from financial income. Also these private investors such as financial companies operate infrastructure facilities for investment collection and benefit creation. Thus financial income could be criteria to make decision for investing financial resources to infrastructure projects.

Common private investors pursuing financial income are public corporation of pension and fund and insurance companies in Korea. These private investors could be more likely to participate in private investment because they usually pursuit stable and steady profits. Therefore in order to estimate proper rate of return for investment to infrastructure projects, investment profit rate of National Pension Service and Korean insurance companies are examined in this section.

Table 5 presents annual investment profit rates of National Pension Service which invested around 7.18 billion USD to infrastructure projects in 2012. Total profit rate from financial investment including consigned investment and Short-term financial product was about $7.0 \%$ in 2012. It is relatively lower than profit rates from other financial investment because National Pension Service mainly has invested in stable bonds. Also investment profit rates are fluctuated in every year. Therefore proper rate of return for investment to infrastructure projects which can be estimated from profit rates of financial investment in the last 6 year could be about $9.7 \%$. 
Table 5. Investment Profit Rate of National Pension Service (Unit: \%)

\begin{tabular}{|c|c|c|c|c|c|c|c|c|c|}
\hline & Bond & $\begin{array}{c}\text { Money } \\
\text { Trust }\end{array}$ & $\begin{array}{c}\text { Time } \\
\text { deposit }\end{array}$ & $\begin{array}{c}\text { Beneficiary } \\
\text { Certificate }\end{array}$ & $\begin{array}{c}\text { Consigned } \\
\text { Investment }\end{array}$ & $\begin{array}{c}\text { Venture } \\
\text { Investment }\end{array}$ & Stock & $\begin{array}{c}\text { Short-Term } \\
\text { Financial } \\
\text { Product }\end{array}$ & Total \\
\hline 1998 & 15.01 & 15.43 & 15.17 & 10.89 & - & - & & & 18.37 \\
\hline 1999 & 12.45 & 17.06 & 15.95 & 14.16 & - & - & & & 24.49 \\
\hline 2000 & 10.99 & 10.26 & 9.23 & -45.69 & -41.87 & - & & & -1.83 \\
\hline 2001 & 8.79 & 11.58 & 5.08 & 30.38 & 63.02 & - & 36.86 & 4.84 & 11.41 \\
\hline 2002 & 9.79 & -15.92 & - & 4.83 & -7.15 & 3.46 & -0.52 & 4.03 & 8.39 \\
\hline 2003 & 5.09 & 14.05 & - & 17.19 & 42.24 & - & 35.08 & 3.93 & 7.58 \\
\hline 2004 & 8.35 & - & 4.30 & 0.59 & 9.22 & - & 10.26 & 3.66 & 8.64 \\
\hline 2005 & 0.58 & - & 3.78 & -74.69 & 62.94 & - & 55.69 & 3.50 & 5.66 \\
\hline 2006 & 5.69 & - & 5.30 & 0.52 & 4.19 & - & 5.66 & 4.19 & 5.77 \\
\hline 2007 & 2.69 & - & - & - & 39.42 & 10.53 & 34.37 & 4.75 & 6.81 \\
\hline 2008 & 10.64 & - & - & - & -40.41 & 1.06 & -37.46 & 5.87 & -0.19 \\
\hline 2009 & 4.08 & - & - & - & 45.09 & 4.60 & 58.65 & -0.49 & 10.41 \\
\hline 2010 & 7.63 & - & - & - & 24.73 & 17.60 & 26.04 & 2.31 & 10.39 \\
\hline 2011 & 5.68 & - & - & - & -10.49 & 6.70 & -10.19 & 3.20 & 2.31 \\
\hline 2012 & 5.95 & - & - & - & 9.78 & 5.14 & 11.01 & 3.16 & 7.00 \\
\hline
\end{tabular}

Source: National Pension Service

Meanwhile, one of the huge private investors for infrastructure projects is insurance companies which have invested over 1 billion USD in infrastructure projects in Korea. According to data from Korea Life Insurance Association, the total profit rate of insurance companies' financial investment in 2012 was about $4.3 \%$ (refer to Table 6). It is similar with total profit rate of National Pension Service because insurance companies also have invested to appropriate investment markets for stable and steady profits. With considering low-interest trend and given data, proper rate of return for investment to infrastructure projects which can be estimated from average profit rate of financial investment of Korean insurance companies could be around $7.5 \%$.

Table 6. Investment Profit Rate of Korean Insurance Companies (Unit: \%)

\begin{tabular}{|c|c|c|c|c|c|c|c|c|c|}
\hline & $\begin{array}{c}\text { Cash and } \\
\text { Deposit }\end{array}$ & Stock & $\begin{array}{c}\text { Government } \\
\text { and Public } \\
\text { Bond }\end{array}$ & $\begin{array}{c}\text { Corporate } \\
\text { Bond }\end{array}$ & $\begin{array}{c}\text { Beneficiary } \\
\text { Certificate }\end{array}$ & $\begin{array}{c}\text { Negotiable } \\
\text { Security }\end{array}$ & $\begin{array}{c}\text { Loan } \\
\text { Bond }\end{array}$ & $\begin{array}{c}\text { Real } \\
\text { Estate }\end{array}$ & Total \\
\hline 1998 & 9.4 & 4.2 & 14.5 & 14.8 & 13.3 & 11.4 & 15.0 & 9.8 & 12.7 \\
\hline 1999 & 5.7 & 54.4 & 10.4 & 13.6 & 9.6 & 22.0 & 11.0 & 2.2 & 12.7 \\
\hline 2000 & 6.8 & 7.8 & 11.5 & 12.2 & 3.8 & 6.5 & 11.3 & 3.6 & 8.9 \\
\hline 2001 & 5.3 & 8.5 & 9.2 & 11.2 & 5.5 & 7.7 & 10.7 & 2.8 & 8.9 \\
\hline 2002 & 5.3 & 5.6 & 8.6 & 8.6 & 5.7 & 5.4 & 10.8 & 3.6 & 8.9 \\
\hline 2003 & 3.2 & 7.4 & 7.4 & 5.2 & 5.0 & 4.4 & 10.6 & 4.1 & 8.3 \\
\hline 2004 & 3.4 & 3.5 & 6.8 & 6.8 & 5.1 & 6.0 & 10.1 & 4.7 & 8.0 \\
\hline 2005 & 4.0 & 5.9 & 5.8 & 6.3 & 4.0 & 6.6 & 9.6 & 4.3 & 7.0 \\
\hline 2006 & 4.3 & 4.1 & 5.1 & 5.1 & 5.6 & 5.2 & 8.3 & 3.3 & 5.6 \\
\hline 2007 & 3.8 & 7.1 & 5.0 & 5.0 & 8.9 & 4.1 & 8.6 & 2.7 & 5.7 \\
\hline
\end{tabular}




\begin{tabular}{|l|l|l|l|l|l|l|l|l|l|}
\hline 2008 & 3.8 & 2.3 & 5.4 & 5.0 & 5.8 & -0.5 & 8.6 & 4.9 & 4.7 \\
\hline 2009 & 2.9 & 3.9 & 5.2 & 5.5 & 3.9 & 4.0 & 7.9 & 4.2 & 5.3 \\
\hline 2010 & 3.3 & 3.2 & 5.2 & 5.1 & 10.2 & 4.2 & 8.2 & 3.0 & 5.7 \\
\hline 2011 & 3.5 & 1.4 & 4.9 & 4.3 & 4.5 & 5.1 & 7.4 & 3.5 & 5.1 \\
\hline 2012 & 3.5 & 0.5 & 4.8 & 4.5 & 3.5 & 5.0 & 6.9 & 3.8 & 4.3 \\
\hline Ave. & 4.5 & 8.0 & 7.3 & 7.5 & 6.3 & 6.5 & 9.7 & 4.0 & 7.5 \\
\hline
\end{tabular}

Source: Korea Life Insurance Association

Based on the above analysis results, proper rate of return for investment to infrastructure projects can be estimated. The average rate of return, $8.6 \%$, between expected profit rate of National Pension Service, 9.7\%, and expected profit rate of insurance companies, $7.5 \%$, could be proper rate of return for financial investment to infrastructure projects. When considering recent circumstances of investment markets, $8.6 \%$ rate of return from infrastructure investment might be appropriate.

\subsection{Proposed Proper Rate of Return on Investments}

As mentioned above, when certain levels of profits will be expected from private investment to infrastructure projects, private investors can decide to invest in infrastructure projects. However it is hard to estimate proper rate of return for private investments to infrastructure projects because economic indicators are very fluctuant and various. For that reason, this study implemented to estimate proper rate of return for private investments using three approaches.

According to estimate proper rate of return as above, minimum $3.8 \%$ to maximum $9.7 \%$ could be estimated for least acceptable rate of return of private investments. This is because there are different criteria for estimate of profit rates among approaches and estimated rate of returns on each existing infrastructure project could be varied depending upon characteristics of projects. Also estimated rate of returns above could be smaller than rate of return from other investment because low-interest rates have continued to be trend and recent private investors make decisions of conservative investments to infrastructure projects rather than aggressive investments.

Therefore, this study suggests 8 9\% rate of return for private investments to infrastructure projects as a threshold of investing to infrastructure projects. Proposed rate of return could be bigger than rate of return on existing private investments, however, could be similar with rate of return on financial investments. This proposed rate of return could be appropriate considering public responsibility and proper profits of private investors.

\section{Conclusion}

Private investment called as joint venture is effective and efficient method to implement infrastructure projects in Korea due to the budget constraint of the government. In order to vitalize private investments, certain level of profits from investment should be guaranteed. Also private investors make decisions to invest to infrastructure projects depending on expected rate of return of long period from investments. Nevertheless proper rate of return for private investment to infrastructure projects is not defined yet because of fluctuating economic indicators and uncertain expectation of economic condition in future. This study proposed the proper rate of return for private investment to infrastructure projects in Korea using three approaches such as estimate from existing private investment projects, various economic indicators and rate of returns on financial investment. 
Estimating rate of returns from existing infrastructure projects involved with private investments are varied depending upon infrastructure types. This study examined 46 existing infrastructure projects and estimated rate of return for rails, ports, roads, environments and other projects. The highest rate of return in project types is rails as $9.18 \%$ and the lowest rate of return in project types is environments as $6.16 \%$. So the average of rate of return of existing infrastructure projects involved with private investment is around $7.8 \%$. In addition, this study examined estimate of risk-free rate of return and rate of return on financial investments and each of rate of return is 3.8 6.4\% and $7.5 \sim 9.7 \%$ respectively.

On the basis of above estimates, this study suggests 8 9\% rate of return for private investment to infrastructure projects as a minimum threshold of profit rate. The proposed rate of return for private investment is naturally bigger than risk-free rate of return and is similar with rate of return on existing infrastructure projects and financial investments. This is because the proposed rate of return could be reflected by recent economic circumstances and risk of investment in long period. However in order to estimate more explainable rate of return for private investment to infrastructure projects, more existing infrastructure projects and economic indicators are needed to be examined in further study.

\section{References}

[1] C. Ko, "A Study of Realization of Government Subsides by Abolition of Minimum Revenue Guarantee (MRG) for Private Transportation Infrastructure Investment Project”, Master Thesis, University of Seoul (2008).

[2] H. Ahn and M. Kim, "Regional Allocation of Transportation Infrastructure Investment and Development of Local Economy", Korea Research Institute for Human Settlements, (2006).

[3] J. Joo, H. Ha and D. Park, "Analysis of Factors of IRRs and Spread on Korean's BTO Projects", Journal of Korean Society of Transportation, vol. 28, no. 2, (2010), pp. 135-150.

[4] Korea Development Institute, Public-Private Partnership in Infrastructure in Korea Brochure, http://kdi.re.kr/ (2013).

[5] M. Do and S. Kwon, "Current Status and Perspectives of Asset Management in South Korea", Proceedings of International Workshop on Asset Management Implementation in Asian Countries, (2009).

[6] M. Suhr and M. Kim, "A Study on the Effective Operation Model of Joint-Venture Contract-With a Focus on the Example of Domestic Construction Industry", Journal of Korea Institute of Construction Engineering and Management, vol. 3, no. 3, (2002), pp. 103-111.

[7] National Assembly Budget Office, Mid-and Long-Term Budget Demand Analysis in National Main Projects, (2009).

[8] Private Infrastructure Investment Center of Korea, PICKO White Paper (1999-2004), (2005)

[9] Public and Private Infrastructure Investment Management Center, Act on Private Participation in Infrastructure, http://pimac.re.kr/, (2010).

[10] S. Back, "A study on the Evaluation of Value for Money in Private Provided Infrastructure with a Focus on BTO Projects", Journal of Korean Society of Transportation, vol. 25, no. 1, (2007), pp. 49-59.

[11] S. Kim, J. Oh and S. Kang, "An Experience of Construction and Operation of the Incheon Airport Exclusive Expressway by Private Capital", Journal of Korean Society of Civil Engineers, vol. 24, no. 2, (2004), pp. 143-148. 
International Journal of Transportation

Vol.3, No.1 (2015) 